\title{
ELECTORAL RIGHTS UNDER THE REVIEW OF THE EUROPEAN COURT OF JUSTICE: JUDICIAL TRENDS AND CONSTITUTIONAL WEAKNESSES
}

\begin{abstract}
Stanislas Adam*
Summary: This article aims to identify the link between EU electoral rights and national citizenship and to situate these rights in the broader context of EU citizenship. For these purposes, two recent judgments of the European Court of Justice regarding EU elections dated 12 September 2006 are discussed (Spain v United Kingdom and Eman \& Sevinger). These judgments establish important principles for the election of the European Parliament, especially the scope ratione personae of recognised electoral rights of EU citizens and the boundaries framing national policies in this respect. They either leave Member States free to apply residence criteria in order to limit the scope ratione personae of EU electoral rights or to invoke their own constitutional traditions to extend that scope. This is not to say, however, that the Member States enjoy complete freedom in this respect. The paper concludes that the current fundaments of EU citizenship are weak in EU primary law, in particular in the field of political rights. For this reason, the European elections and, more generally, the European democratic process should be discussed once again at the highest political level.
\end{abstract}

\section{Introduction}

The European Court of Justice (hereinafter ECJ) rarely deals with electoral rights ${ }^{1}$ but has never addressed the matter of rights to vote and stand as a candidate in elections for appointment to the European Parliament. Recently, however, the ECJ's Grand Chamber has had to deal with questions concerning the identity of persons who enjoy active and pas-

\footnotetext{
* Stanislas Adam, PhD Fellow of the Research Foundation - Flanders (FWO), Ghent University (European Institute); Academic Consultant, University of Namur (Projucit Research Centre, <http://www.projucit.be/>). The author would like to thank Dr Kirstyn Inglis, Dr Peter Van Elsuwege (Ghent University) and the scientific committee of this review for their thoughtful comments on earlier drafts of the present article. The usual disclaimer applies. This paper was first submitted in April 2007.

1 One of the sole examples was the procedure initiated by the Commission against Belgium for not having brought into force within the prescribed period the laws, regulations and administrative provisions necessary to comply with Council Directive (EC) 94/80 of 19 December 1994 laying down detailed arrangements for the exercise of the right to vote and stand as a candidate in municipal elections by citizens of the Union residing in a Member State of which they are not nationals. See ECJ Case C-323/97 Commission v Belgium [1998] ECR I-4281.
} 
sive voting rights in European elections, and has issued two important judgments. ${ }^{2}$

The first case (Spain $v$ United Kingdom) was a consequence of the Matthews judgment of the European Court of Human Rights (hereinafter ECtHR). ${ }^{3}$ In this judgment, the ECtHR decided that the European Parliament (hereinafter EP) must be qualified as a 'legislative organ' in Gibraltar. As a consequence, the United Kingdom was obliged to organise European elections there. However, according to its electoral traditions, the United Kingdom extended active and passive voting rights in European elections to certain persons that are not UK nationals. It recognised these rights for non-UK nationals who are Commonwealth citizens, namely Qualifying Commonwealth Citizens (hereinafter QCCs) residing in Gibraltar. Generally, a Member State may grant higher standards of rights than those prescribed by international law, such as Article 3 of the First Protocol to the Convention for the Protection of Human Rights and Fundamental Freedoms (hereinafter ECHR). Questions arise, however, as to the limits to EU citizenship as set down by primary EC law: can (primary) Community law limit the freedom of the Member States to provide third-country nationals with the right to vote at European elections and perhaps, even, the right to be elected to the EP?

In the second case (Eman \& Sevinger) the Raad van State of the Netherlands (hereinafter Dutch supreme administrative court) asked the ECJ to give a preliminary ruling on the freedom for a Member State to exclude some of its own citizens from those voting rights when they reside in overseas countries. ${ }^{4}$ It is important to emphasise that the Court

\footnotetext{
2 See ECJ Case C-145/04 Spain v United Kingdom [2006] ECR I-7917 and Case C-300/04 Eman \& Sevinger [2006] ECR I-8055. See first comments in F Kauff-Gazin, 'Droits de vote et d'éligibilité au Parlement européen' (2006) Europe 8; A Dawes (2006) 3 RDUE 707-712; M Claes (2007) 5 SEW 216-221; L Burgogue-Larsen, 'L'identité de l'Union européenne au cœur d'une controverse territoriale tricentenaire. Quand le statut de Gibraltar réapparaît sur la scène judiciaire européenne' (2007) 1 RTDE 25-45; E Broussy, F Donnat and C Lambert, 'Actualité du droit communautaire' (2006) AJDA 2271-2272.

3 See ECtHR Case Matthews $v$ United Kingdom [1999] App $\mathrm{n}^{\circ} 24833 / 94$ para 54. See $\mathrm{P}$ Tavernier (2000) JDI 2000 97-102; A Bultrini, 'La responsabilité des Etats membres de l'Union européenne pour les violations de la Convention européenne des droits de l'homme imputables au système communautaire' (2002) RTDH 20-23; RA Lawson, 'Comment' (1999) 10 SEW 390-392. See in particular, on this evolution, C Desmecht, 'Le droit aux élections libres dans la Convention européenne des droits de l'homme' (2002) CDPK 480-481; R Ergec, Protection européenne et internationale des droits de l'homme (Mys \& Breesch CDPK Libri, Ghent 2000) 8; G Goedertier and Y Haeck, 'Artikel 3 Eerste Protocol. Recht op vrije en geheime verkiezingen' in J Vande Lanotte and Y Haeck (eds), Handboek EVRM (Intersentia, Antwerpen 2004-2005) 466-467; S Van Drooghenbroeck, La Convention européenne des droits de l'homme: trois années de jurisprudence de la Cour européenne des droits de l'homme (1999-2001) (Larcier - Les dossiers du Journal des Tribunaux, Bruxelles 2003) 225-226.

4 In Aruba, in this case.
} 
followed the tendency of the ECtHR and without any difficulty accepted residence as a limit to voting rights. EC law does not apply in Aruba and hence the EP cannot be considered as a legislative organ there. Thus, neither EC law nor the ECHR or its protocols are capable of granting directly to Eman and Sevinger - who are living in Aruba - the right to vote and stand as a candidate in European elections. The problem here was that Dutch electoral law excluded its own nationals from these elections only when they resided in Aruba and the Dutch Antilles, and not elsewhere in the world. The ECJ was asked to give its ruling on this distinction.

The recent judgments of the ECJ establish important principles on the election of the EP, especially the scope of recognised electoral rights of EU citizens and the boundaries framing national policies in this respect. They either leave Member States free to apply residence criteria in order to limit the scope ratione personae of EU electoral rights or leave Member States free to invoke their own constitutional traditions to extend that scope. However, as will be discussed further, this is not to say that the Member States enjoy complete freedom in the determination of the scope ratione personae of $\mathrm{EU}$ electoral rights.

The solutions provided by the ECJ can be criticised on a number of grounds. The first section of the paper analyses active and passive electoral rights in European Parliament elections (see II below) and the subsequent section aims to identify the practical consequences of the above-mentioned case law of the ECJ (see III below). However, those judgments would lose much of their interest if they were not placed in the broader context of European citizenship. A dichotomy arises here: on the one hand, we have the proactive intervention of the ECJ in the field of the right of Union citizens and their family members to move and reside freely within the territory of the Member States; on the other hand, there are important - and even constitutional - limits to rights of political participation in the framework of European citizenship, even if the ECJ seems to have framed the boundaries of the exercise of the Member States' freedom in this respect (see IV below).

\section{The right to vote and stand as a candidate in European elections: an important step but unfinished move towards EU collective identity}

\section{The growing but nonetheless contested idea of a Europe of citizens}

While the founding fathers could not have imagined all the consequences of their work, they were not unaware of the importance of the individual for the success of their aims. ${ }^{5}$ Almost twenty years after the

\footnotetext{
5 See J Monnet, Mémoires (Fayard, Paris 1976) 427. See also R Kovar and D Simon, 'La citoyenneté européenne' (1993) CDE 285.
} 
signing of the Treaty of Rome, however, very little had been done to grant rights to individuals beyond the group of economically active migrants. The President of the Council at that time, and Belgian Prime Minister, Leo Tindemans, proclaimed in a famous report following the 1974 Paris Summit that a specific European citizenship was indispensable to consolidate the European project. ${ }^{6}$ Despite some initiatives of the Commission, the European Council and the EP, no consensus was reached before the 1992 Maastricht Treaty. This failure is understandable from a historical point of view. At the end of the seventies and during the eighties, European citizenship was considered by 'Eurosceptics' as an extension of Europe far beyond the international scope of the founding Treaties. The internal market was then still largely ineffective and the settlement of rights common to all EU citizens, including electoral rights, was therefore no priority. ${ }^{7}$ The EP, with its 'Seitlinger project', recommended that the Member States grant their own nationals the right to vote in European elections wherever they resided in the Community. However, this recommendation was not binding. ${ }^{8}$ Some Member States improved their laws on this point, but always on grounds of isolated and spontaneous initiatives. ${ }^{9}$ In sum, the sole but nonetheless essential progress made during this period was the first direct elections of the EP in 1979. As the 1976 Act concerning the Election of the Representatives of the European Parliament by Direct Universal Suffrage ${ }^{10}$ illustrates, this improvement was not accompanied

6 See 'Tindemans-report' [1976] Bull.EC Suppl. 1/76 5-31.

7 See on this evolution C Wihtol de Wenden, 'Les fondements de la citoyenneté européenne' in S Leclerc and J-F Akandji-Kombé (eds), La citoyenneté européenne (Bruylant, Brussels 2007) 25-26; A Connolly, S Day and J Shaw, 'The Contested Case of EU Electoral Rights' in R Bellamy, D Castiglione and J Shaw (eds), Making European Citizens. Civic Inclusion in a Transnational Context (Palgrave/MacMillan, New York 2006) 35-43; K Lenaerts, P Van Nuffel and R Bray (eds), Constitutional Law of the European Union ( $2^{\text {nd }}$ edn Thomson - Sweet \& Maxwell, London 2006) 541-543; J Pomoell, European Union Citizenship in Focus : the Legal Position of the Individual in EC Law (Helsinki University Press Forum Iuris, Helsinki 2000) 78-80; L Le Hardÿ de Beaulieu, 'Quelques propos sur la notion de citoyenneté européenne' in L Le Hardÿ de Beaulieu (dir), L'Europe et ses citoyens. Actes du Colloque 'Où en est l'Europe des citoyens? Vingt ans après l'élection du Parlement européen au suffrage universel' (P.I.E. - Lang, Brussels 2000) 10-12; J-L Guermonne, Le système politique de l'Union européenne (Montchrestien, Paris 1998), 130-133; P Magnette, La citoyenneté européenne. Droits, politiques, institutions (Editions de l'U.L.B., Brussels 1999); P D’Argent, 'Le droit de vote et d'éligibilité aux élections municipales et européennes comme attribut de la citoyenneté de l'Union' (1993) Ann. Dr. Louv. 222-226.

8 [1983] OJ C 300/77.

9 This was the case in Belgium, the United Kingdom, the Netherlands and Ireland. See PM Mabaka, Problèmes et perspectives constitutionnels du processus de l'intégration européenne - Aspects nationaux et européen (Ant. N. Sakoulas/Bruylant coll. Bibliothèque européenne, Athens/Brussels 2006) 196-198.

10 Annex to Decision 76/787/ECSC, EEC, Euratom of 20 September 1976 relating to the Act concerning the election of the representatives of the Assembly by direct universal suffrage [1978] OJ L278/1. This annex has since then been completed and amended by Decision 2002/772/CE-Euratom of 25 June 2002 and 23 September 2002 [2002] OJ L283/1. 
by substantial EU political rights. In particular, there existed at that time no freedom of movement of voters in European elections.

\section{Maastricht and EU citizenship}

The Maastricht Treaty created a Union, an impetus for the development of the collaborative projects of the Member States outside the traditional EC economy-linked policies. The spirit of this reform was to deeply enhance the common values not only of the Member States but also of their citizens. The latter were thus granted the official status of European citizens by Article 17 EC. This provision stipulates moreover that, '[c]itizenship of the Union shall complement and not replace national citizenship'. A large majority of authors interpreted this as meaning that only EU nationals may benefit from citizenship and the rights attaching to it. ${ }^{11}$ One of the prerogatives specifically linked to EU citizenship is the right for each EU citizen to take part, whether actively or passively, in municipal and European elections in a Member State of which he/she is not a national and under the same conditions as nationals of that State. This holds true irrespective of the length of stay in the Member State of residence. An exception, however, was allowed for Luxemburg, where five effective years of residence are required. This rule cannot be applied to EU citizens who have lost those electoral rights in the Member State where they are nationals simply because they reside outside the national territory. ${ }^{12}$ The fact that the new chapter on EU citizenship did not generalise the 'free movement of the voters' to all kinds of elections but rather limited its standards to municipal and European elections received much criticism. It was argued that an authentic political Union would have required that EU citizens should enjoy the right to vote and stand as a candidate in all types of elections - regional and national - and irrespective of place of residence. ${ }^{13}$

The EC Treaty adds that the EP represents the "peoples of the States brought together in the Community'14 and that 'the assembly shall draw

11 R Kovar and D Simon (n 5) 292; PM Mabaka (n 9) 194; R Mehdi, 'Article II-99' in L Burgogue-Larsen, A Levade and F Picod, Traité établissant une Constitution pour l'Europe, commentaire article par article. Partie II. La Charte des droits fondamentaux de l'Union (Bruylant, Bruxelles 2005) 507-510. Cf L Le Hardÿ de Beaulieu (n 7) 13. This author admitted that a State was free to grant electoral rights at European elections to non EU citizens (see in particular n 8).

12 Luxemburg Electoral Law of 18 February 2003 [2003] Rec. A-30 445-508 art $35^{\circ}$ and 285 para $14^{\circ}$. Forty-five days of effective residence are required in the Czech Republic (Act 62/2003, 18 February 2003).

13 See M Anderson, M Den Boer and G Miller, 'European Citizenship and Cooperation in Justice and Home Affairs' in A Duff, J Pinder and R Pryce (eds), Maastricht and Beyond. Building the European Union (Routeledge, London 1994) 111.

14 See Art 189 EC. 
up a proposal for elections by direct universal suffrage in accordance with a uniform procedure in all Member States or in accordance with principles common to all Member States'. ${ }^{15}$ Such a proposal requires unanimity in the Council. A directive was adopted on this legal base. This legislation settles basic rules to be applied by Member States in order not to discriminate among EU citizens on grounds of nationality when organising European elections. ${ }^{16}$ Article 1 of this Directive leaves Member States free to limit the right to vote and stand as a candidate in European elections for their own citizens who reside in another Member State. ${ }^{17}$ As a result of the quite recent agreement of the United Kingdom to set aside its traditional principle of majority representation for the purpose of European elections, these have to be organised following the system of proportional representation. ${ }^{18}$ As for the European Charter of Fundamental Rights, this document simply repeats, on the one hand, the right to vote and stand as a candidate in European elections flowing from Article 19 EC and, on the other hand, the principle that European elections must be held according to universal, free and secret suffrage. ${ }^{19}$

Significantly also, as has already been mentioned, the case law of the ECtHR has now made clear that the granting of active and passive voting rights in European elections was no longer ancillary but compulsory for EU Member States, since they are members of the Council of Europe and, as a consequence, bound by the ECHR and its compulsory Protocols. This is both the result of Article 3 of the First Additional Protocol to the ECHR and of the EP competences under its legislative functions. ${ }^{20}$

Such a conclusion does not mean that the Strasbourg Court obliges the Member States to grant foreigners such rights. It is still accepted that a State may exclude third-country nationals from elections. ${ }^{21}$ Active and

\footnotetext{
15 See Art 190(4) EC.

16 See Council Directive (EC) 93/109 of 6 December 1993 laying down detailed arrangements for the exercise of the right to vote and stand as a candidate in elections to the European Parliament for citizens of the Union residing in a Member State of which they are not nationals [1993] OJ L329/34. See for a deep analysis of this instrument N Clinchamps, Parlement européen et droit parlementaire. Essai sur la naissance du droit parlementaire de l'Union européenne (LGDJ, Paris 2006) 84-88. See also the recent proposal of the Commission to amend Directive (EC) 93/109, especially in order to simplify the administrative procedures required to vote in European elections, COM(2006) 791 final.

17 One should not forget that those citizens will enjoy those rights in the Member State of residence, as a result of Art 19 EC.

18 See 1976 Act (n 10) Art 1.

19 See Art 39. This Charter has currently no binding force. See, however, ECJ Case C540/03 Parliament $v$. Council [2006] ECR I-5769 para 38.

20 The Matthews judgment settled in this way an ancient controversy between the ECtHR and the now disappeared European Commission on Human Rights. See n 3.

21 See European Commission on Human Rights Case W, X, Y and $Z v$ Belgium [1975] App $n^{\circ} 6745$ and 6746/74; European Commission on Human Rights Case X $v$ United Kingdom
} 
passive voting rights of those nationals with dual-nationality can also be limited when rules of international private law lead to the consideration that the foreign nationality is the leading one. ${ }^{22}$ To some extent, and as explained below, such solutions are a consequence of Article 16 ECHR, which provides that 'nothing in Article 10, 11 and 14 shall be regarded as preventing the High Contracting Parties from imposing restrictions on the political activity of aliens'. However, the criterion of nationality is nowhere explicitly mentioned by the ECtHR. In other terms, the ECtHR refuses to express its broad consent of limitations of third-country nationals' electoral rights. This observation holds true for all types of elections, not only local or regional but also legislative ones. This could be an indication of the awareness of the ECtHR that the active participation of foreigners in public affairs is a normal evolution towards higher levels of democracy and human rights in Europe, even if in practice the nationality condition is still crucial for the States. Suffice it to note that old members of the Council of Europe, such as France, Belgium, Luxemburg and Germany, still exclude foreigners from most electoral processes, above all legislative ballots. This draws severe criticism from commentators, specifically in view of the evolution initiated by European citizenship and the right of each national of a Member State of the EU to vote in municipal and European elections irrespective of his/her place of residence. ${ }^{23}$ Some argue that nothing can explain the refusal to grant non-EU citizens equal rights, at least when they have been residing in a Member State for a long time. ${ }^{24}$

[1976] App $\mathrm{n}^{\circ}$ 7566/76; European Commission on Human Rights Case $X v$ United Kingdom [1979] App $n^{\circ} 7730 / 76$; European Commission on Human Rights Case Luksch v Italy [1997] App n²7614/95; ECtHR Case Hirst $v$ United Kingdom [2005] App n ${ }^{\circ}$ 74025/01 (see the dissenting opinion of Judges Wildhaber, Costa, Lorenzen, Kovler and Jebens at paras 4 and 8). See also the dissenting opinion of Judge Bonello in the ECtHR Case Ždanoka $v$ Latvia [2004] App $n^{\circ} 58278 / 00$ para 4.3. This solution is not in contradiction with the International Covenant on Civil and Political Rights that foresees that '(e)very citizen shall have the right and the opportunity, without any of the distinctions mentioned in article 2 and without unreasonable restrictions: (a) to take part in the conduct of public affairs, directly or through freely chosen representatives; (b) to vote and to be elected at genuine periodic elections which shall be by universal and equal suffrage and shall be held by secret ballot, guaranteeing the free expression of the will of the electors' (emphasis added).

22 See European Commission on Human Rights Case Ganscher v Belgium [1996] App n ${ }^{\circ}$ 28858/95. See, however, for an opposing solution between EU Member States, ECJ Case C-369/90 Micheletti [1992] ECR I-4239 para 15.

23 See G Goedertier and Y Haeck (n 3) 488. See also P Van Dijk and GJH Van Hoof, De Europese conventie in theorie en praktijk (Ars Aequi Libri, Nijmegen 1990) 1150-1151; S Leclerc, 'Les droits du citoyen européen', in S Leclerc and J-F Akandji-Kombé (eds), La citoyenneté européenne (Bruylant, Brussels 2007) 77. See, however, B Renauld, 'Le droit de vote des étrangers aux élections communales' (2006) 31 JT 578.

24 See the Code of good practice in electoral matters - Guidelines and explanatory report, European Commission for Democracy through Law (Venice Commission), $51^{\text {st }}$ and $52^{\text {nd }}$ sessions (2002) <www.venice.coe.int/docs/2002/CDL-AD(2002)023rev-e.pdf> accessed 15 March 2007. See also G Goedertier and Y Haeck (n 3). 


\section{The double lack of harmonisation regarding the elections of the EP: irreversible deficiencies?}

Two deficiencies characterise current Community law in the context of the elections of the European Parliament.

Firstly, no uniform electoral procedure nor a fortiori any constituency exists at EU level. ${ }^{25}$ The statement by the European Commission that European elections are organised following 'common principles' amongst the Member States is thus a little misleading. ${ }^{26}$ Each State rather constitutes an area where a predefined number of seats must be attributed. Member States may choose to divide their territory into several regional constituencies for the purposes of elections to the EP. ${ }^{27}$ Almost all technical rules that regulate this election are elaborated at the level of the Member States. ${ }^{28}$ This can be illustrated by many examples. Although Member States recently agreed to share the proportional representation principle for the organisation of the European elections, they are almost free to give any practical content to it. As a matter of fact, there are today almost as many proportional representation regimes as there are Member States. ${ }^{29}$ For instance, some States apply blocked list polls while others authorise the voter to give preference to several candidates on different lists (panachage). In accordance with the principle of subsidiarité, the minimum age required to stand as a candidate also varies from one Member State to another. For example, whereas in Denmark, Germany, Spain, Luxemburg, the Netherlands and Finland it is sufficient to be eighteen, in Greece, Italy and Cyprus candidates have to be twenty-five. A third illustration concerns the fact that Member States are not obliged to organise, nor prevented from holding, elections to the EP simultaneously with other elections. Thus, in Belgium European elections take place the same Sunday as elections to the parliaments of the federal entities. ${ }^{30}$ This is feasible in practice because those assemblies, like the EP, have a fiveyear mandate. The opposite is true in Sweden where all internal elections (municipal and national) are organised every fourth year.

Secondly, the identity of the beneficiaries of EU electoral rights whether for European or municipal elections - is broadly determined at

\footnotetext{
25 See P Magnette (n 7) 92. See also G De Vries, 'La procédure électorale uniforme du Parlement européen: un pas pour rapprocher l'Europe des citoyens' (1996) 399 RMCUE 417 to 421 .

26 European Commission Fourth Report on European Citizenship (1 May 2001 - 30 April 2004) of 26 October 2004, COM(2004) 695 final, 8.

27 See for example Belgium, the United Kingdom or Germany.

28 See Decision 2002/772 (n 10) Preamble and Art 7.

29 See B Dollez, 'Vingt-cinq modes de scrutin différents' 2 June 2004, Le Figaro 6.

30 See Act of 10 December 1998, MB of 31 December 1998.
} 
national level. Member States are exclusively competent to grant nationality and they decide who enjoys EU citizenship. ${ }^{31}$ We will come back to this point when examining the delicate question of granting electoral rights to non-EU citizens.

There have been some proposals to modify this situation. During their meeting in Tampere in 1999, the Heads of State or Government of the Member States expressed the wish to grant nationality of the State of residence to third-country nationals residing in the Community for a long period. ${ }^{32}$ A year later, the European Commission presented its project for 'civic citizenship' which was to be inserted in the Charter of Fundamental Rights of the EU. The proposal did not directly deal with nationality issues. Rather, it aimed at providing some EU citizenship rights to thirdcountry nationals, including the right to vote and stand as a candidate in European elections. ${ }^{33}$ Of course, the Commission's proposal only foresaw the granting of such rights to foreigners who have been residing in a Member State for a minimum period. The degree of citizenship even progressed in accordance with the length of the stay in the EU. Several legislative resolutions of the EP shared those views. ${ }^{34}$ Those initiatives have not yet been followed by the Member States, and EU law remains silent on the 'electoral status' of third-country nationals. Thus, the directive concerning the status of third-country nationals who are long-term residents makes no mention of their electoral rights ${ }^{35}$ since, according to the Commission itself, the European Community enjoys no competence in this field. ${ }^{36}$

The Treaty establishing a Constitution for Europe, ${ }^{37}$ the viability of which is now doubtful, provides no evolution in this respect either. The fact that currently the EP barely represents European peoples but is widely

\footnotetext{
31 This expressly results from a Declaration annexed to the Maastricht Treaty about the nationality of a Member State. This document provides that such questions are to be resolved only at national level.

32 Conclusions of the European Council, Tampere, 15 and 16 October 1999, point III.21 <www.europarl.europa.eu/summits/tam_en.htm> accessed 15 March 2007.

33 Communication of the European Commission to the Council and the European Parliament of 22 November 2000 on a Community Immigration Policy, COM(2000)757 final 2122 .

34 See A5-0050/2000 [2000] OJ C377/344 n 19; A5-0223/2001 [2002] OJ C65E/267 n 123; A5-0451/2002 [2004] OJ C038E/247 n 136; A5-0281/2003 [2004] OJ C076E/412 $\mathrm{n}$ 130. Whereas the first Resolution requires residence of at least five years in a Member State, the three others only require three years.

35 [2004] OJ L16/44.

36 Commission's Proposal of 13 March 2001 for a Council Directive concerning the status of third-country nationals who are long-term residents, COM(2001)127 final, 8.

37 [2004] OJ C310/1.
} 
made up of national delegations was not sufficient to lever change. ${ }^{38}$ The Laeken Declaration, which created the Convention and formulated the main questions to be resolved by the next institutional reform, explicitly encouraged debate on the need to revise the regime governing European elections, for example by creating a homogeneous constituency at the EU level. ${ }^{39}$ The EP, following the Commission, proposed an application of this European electoral area for the election of ten percent of the members of the EP. ${ }^{40}$ The idea was not only to improve the visibility of the EP for EU citizens but also to form the Commission - at least partially - with European-calibre politicians who won their seat in the EP after a European electoral challenge. In other words, the establishment of a European constituency and a more democratic composition of the Commission were supposed to increase people's interest in EP elections. ${ }^{41}$

The preparatory works of the Constitutional Treaty raised discussions on such issues. For instance, a debate was held on the rationalisation of the electoral procedure. This concerned three aspects, namely the creation of supranational constituencies made up of several Member States, grouped following cultural and linguistic affinities, the drastic limitation of the number of candidates and seats to be attributed within the EP, and the establishment of a unique list made up of all candidates of a constituency and their preferential classification by the voters. ${ }^{42}$ All of these proposals were rejected in the end. The sole progress made is the assertion in the text of the Constitutional Treaty that the EP is composed of 'representatives of the Union's citizens'. ${ }^{43}$ The reference made in Articles 189 and 190 EC to the 'peoples of the States brought together in the Community' is thus replaced by a more federalist and cohesive vision of EU citizenship. This is, however, a purely symbolic improvement. And even this symbolic upgrading is altered by the preamble of the Constitutional Treaty which recalls that '[the peoples of Europe], while remaining proud of their own national identities and history, $[. .$.$] are determined to transcend their former divi-$

38 P Lamy and J Pisani-Ferry, The Europe We Want (Plon - Policy Network, Paris 2002) 75 and 76.

39 Annex I to the Council conclusions [2001] SN 300/1/01 REV 23.

40 See A4-0212/98 [1998] OJ C292/66 and the Communication of the Commission of 4 December 2002 on the institutional architecture for the European Union: peace, freedom, solidarity, COM(2002)728 final 16. The Resolution of the Parliament was adopted on the basis of the so-called 'Anastassopoulos' report.

41 See on this point the Legislative Resolution of the European Parliament of 12 June 2002 on the draft Council Decision amending the Act concerning the election of representatives of the European Parliament by direct universal suffrage, annexed to Council Decision 76/787/ ECSC, EEC, Euratom of 20 September 1976 A5-0212/2002 [2003] OJ C261/306.

42 See CONV 585/03, CONTRIB 261, 27 February 2003. This project, presented by John Burton, is available at <www.register.consilium.eu.int/pdf/fr/03/cv00/cv00585fr03.pdf> accessed 15 March 2007.

43 See Art I-20 (2). 
sions and, united ever more closely, to forge a common destiny'. ${ }^{44}$ For the rest, the Constitutional Treaty only repeats what already exists: EU citizenship is additional to national citizenship and does not replace it; ${ }^{45}$ every EU citizen has the right to vote and stand as a candidate in European and municipal elections in his state of residence, under the same conditions as the nationals of this Member State; ${ }^{46}$ the members of the EP must be elected by direct universal suffrage in a free and secret ballot. ${ }^{47}$ In particular, no softening of the procedure for the harmonisation of the European elections can be found in the Constitutional Treaty. ${ }^{48}$

Finally, and as already mentioned, the Constitutional Treaty makes no mention of electoral rights of third-country citizens. The problem of the electoral status of third-country nationals is nevertheless a fundamental one given the increasing immigration in western European countries. Some Member States have large non-national minorities which are almost completely excluded from any political participation. A good illustration of this is the situation of so-called non-citizens in Latvia, namely Sovietera immigrants who have not been granted Latvian citizenship since the restoration of Latvian independence in $1991 .{ }^{49}$ The sole evolution provided by the Constitutional Treaty in this respect consists of recognising the right of each person to good administration and the right of access to documents, irrespective of his/her nationality. ${ }^{50}$ Those rights complete the EC Treaty, which already granted rights for each person to refer cases of maladministration to the European Ombudsman and to petition the European Parliament. ${ }^{51}$ Nevertheless, the problem of the electoral rights of third-country citizens was addressed during the preparatory works of the European Convention. Following the calls made during earlier intergovernmental conferences, some members of the Convention pondered potential evolutions regarding the political rights of third-country na-

44 Emphasis added.

45 See Art I-10 (1).

46 See Art I-10 (2) b and II-99.

47 See Art I-20 (3).

48 See Art III-330 and Art III-126. Unanimity is required in the Council to adopt harmonising measures. Finding a compromise is therefore extremely difficult with twenty-seven Member States, unless, perhaps, on purely technical aspects.

49 This category of persons represents approximately twenty percent of the Latvian population. Similar problems exist in Estonia, even though the number of non-citizens in this country is less than ten percent. Moreover, non-citizens in Estonia have the right to vote in municipal elections, which is not the case in Latvia. See on these questions P Van Elsuwege, 'Russian-Speaking Minorities in Estonia and Latvia: Problems of Integration at the Threshold of the European Union' (2004) 20 ECMI Working Paper, 49-51 <www.ecmi.de> accessed 15 March 2007.

50 See Art III-101 and 102.

51 See Art II-103 and 104. 
tionals legally residing in the European Union. Kaufmann and Carnero (members of the EP) and Borell and Garrido (members of the Spanish Parliament) argued that EU citizenship should be granted directly by the Constitution to third-country nationals who have been residing in Europe for a long period. ${ }^{52}$ Berès, Duhamel, Paciotti and Van Lancker (members of the EP), and Floch (member of the French Assemblée Nationale) rather supported the inscription in the text of the Constitution of a possibility in this sense. ${ }^{53}$ Other proposals were to confer EU citizenship on stateless persons and refugees. ${ }^{54}$ The divergent views of the Member States made it impossible to reach a compromise in this respect. Spain even declared in an annex to the Constitutional Treaty that "only nationals of Member States are entitled to the specific rights of European citizenship unless Union law expressly provides otherwise'. ${ }^{55}$ Accordingly, not only EU citizenship as a global concept but also all specific rights linked to it are exclusively granted to EU nationals. This would be the case for active and passive electoral rights in European and municipal elections. ${ }^{56}$ Civic citizenship defended by the Commission was thus rejected.

\section{The role of the ECJ in identifying persons who enjoy the right to vote and to stand as a candidate in European elections: first jurisprudential indications}

Now that the framework of European (political) citizenship has been described, it is important to come back to the judgments of the ECJ of September 2006 and to assess their impact on EU electoral rights. Both cases raise interesting problems. The first concerns access to active and passive electoral rights for third-country nationals (I). The second revolves around the possibility for Member States to exclude their own citizens from those rights because they do not reside in their national territory (II).

\section{Are Member States free to grant third-country nationals the right to vote and stand as a candidate at European elections?}

Case C-145/04 directly follows the famous and much commented Matthews judgment of the ECtHR. ${ }^{57}$ In the Matthews judgment, the EC-

\footnotetext{
52 See Proposed amendments VII(1)7 and VII(2) $12<$ www.european-convention.eu.int> accessed 15 March 2007.

53 See Proposed amendments VII(1)18 and VII(2)6.

54 See Proposed amendments VII(1)13 (J Voggenhuber and E Lichtenberger) and VII(1)16 (M Nagy).

55 Declaration 47 by the Kingdom of Spain on the definition of the term 'nationals'.

56 The United Kingdom made a Declaration $\left(\mathrm{N}^{\circ} 48\right)$ to the contrary.

57 See $\mathrm{n} 3$.
} 
tHR confirmed that a Member State of the EU can be held responsible for a breach of the ECHR by a provision of EU primary law if that primary law provision is incapable of existing without the consent of all Member States. ${ }^{58}$ The facts were as follows: Mrs Matthews, a British citizen, was excluded from voting in European elections because she lived in Gibraltar. This was the result of an Annex to the 1976 Act related to European elections, which forbids the United Kingdom from organising them outside its own territory ${ }^{59}$ even though Community law applies in Gibraltar, since this is a territory for whose external relations UK is responsible. ${ }^{60}$ Mrs Matthews had brought an action before national courts without obtaining any satisfaction, and so brought her case before the ECtHR in Strasbourg. Her main argument was that the United Kingdom had breached her right to free elections guaranteed by Article 3 of the First Additional Protocol to the ECHR.

After having lost the case before the ECtHR, the United Kingdom made efforts to obtain, if not the total removal, at least an amendment of the Annex. Spain, however, persisted in refusing any change in this respect for political and historical reasons. Consequently, during a meeting of the Council of 18 February 2002, the United Kingdom declared that all necessary modifications of its legislation would be made in according with the requirements of the Matthews judgment.

The European Parliament Representation Act 2003 was thus adopted. This law binds Gibraltar to an existing constituency in the United Kingdom ${ }^{61}$ and, furthermore, this Member State grants the right to vote and to stand as a candidate in European elections not only to EU citizens - including British citizens - but also to certain Commonwealth citizens who are not nationals of an EU country, namely ' $\mathrm{BCCs}$ '.

Spain refused to accept this extension. It firstly complained before the European Commission, which considered the case too politically sensitive to receive a clear-cut answer. ${ }^{62}$ Spain then brought the United Kingdom before the ECJ to obtain recognition of UK's failure to respect EC law. It is important to distinguish the two legal arguments invoked by Spain.

\footnotetext{
58 In other terms, the contested norm would not exist should the Member State in question not have accepted it.

59 This was before Annex II but it became Annex I after the renumbering operated by the Council Decision of 25 June and 23 September 2002, above n 10. In the rest of the text, we shall speak, for clarity, of Annex I.

60 Art 299(4) EC.

61 In the United Kingdom, several electoral constituencies exist for the purposes of European elections.

62 See the Declaration of the College of the European Commission of 29 October 2003, Press Release IP/03/1479.
} 
The Kingdom of Spain argued with its first means of action that the EC Treaty as such forbids a Member State from granting third-country nationals EU citizenship rights. According to the Kingdom of Spain, the ECJ should take into account - when deciding whether a QCC could have the right to vote and stand as a candidate at European elections in Gibraltar - the declaration made by the United Kingdom itself in 1982 on the definition of the term 'nationals' for the purposes of EC law. ${ }^{63}$ Yet, the United Kingdom was not disputing that $\mathrm{QCCs}$ are not within the categories set out in this Declaration. Spain wanted to use this fact to deny QCCs any voting rights in European elections. Spain then relied on the narrow link between, on the one hand, Articles 17 and 19 EC combined with the notion of EU citizenship, with, on the other hand, the nationality of a Member State. Articles 189 and 190 EC, which describe the EP as an assembly made up of representatives of the "peoples of the States brought together in the Community', would confirm this conclusion. This is consistent with the general thrust of commentators at the time on the introduction of EU citizenship in the EC Treaty: surely the fact that the EC Treaty grants EU citizenship to nationals of the Member States and enumerates a list of rights linked to it necessarily means that those rights belong exclusively to EU nationals.

However, both the Advocate General Tizzano and the ECJ have rejected this argument. ${ }^{64}$ The ECJ argues that the 1982 Declaration made by the United Kingdom, although important, only concerned the scope of those provisions of the EC Treaty that refer to the concept of 'national', such as the provisions relating to the freedom of movement of persons. Contrary to what the Kingdom of Spain argued, this Declaration could not therefore be used to prevent the extension of EU voting rights to QCCs when residing in Gibraltar. ${ }^{65}$ Moreover, besides the fact that the 'people' is a vague concept from which no unambiguous conclusion is possible, Article $19 \mathrm{EC}$ only deals with the electoral rights of EU citizens who are freely circulating within the Union. This provision does not concern the political rights of third-country nationals. Article $17 \mathrm{EC}$, for its part, only means that the status of national of a Member State confers EU citizenship in principle. Again, the purpose of this article is not to exclude non-EU citizens from Union citizenship. Nor is it to forbid a Member State from granting EU citizenship rights to third-country nationals. This would be confirmed, implicitly, by the EC Treaty itself when it grants

\footnotetext{
63 This would follow from the judgment of the ECJ in Kaur. See ECJ Case C-192/99 Kaur [2001] ECR I-1237 para 24.

64 Conclusions of AG Tizzano of 6 April 2006 in Cases C-145/04 and C-300/04, paras 72 to 93. See also Case C-145/04 (n 2) 66 to 80.

65 Case 145/04 para 75.
} 
each person, irrespective of his/her nationality, the right to petition the $\mathrm{EP}$ or to refer cases of maladministration to the European Ombudsman.

The Court adds a more practical consideration. Were a Member State to grant citizens of third-countries the right to vote and to stand as candidates in European elections, this would in no way affect the proportional importance of this State within the EP. The same holds true for the size and the identity of other Member States' delegations in the EP. Considering that Member States are - as mentioned above - almost totally free to organise elections to the EP, and also that this kind of evolution is not prejudicial to the other parties to the EC/EU Treaties, the conclusion must be that Member States may recognise the right of third-country nationals to take part in elections to the EP. ${ }^{66}$ The consequent possibility that a third-country national might take a seat as a Member of the European Parliament is not analysed by the ECJ. In all probability, the Court was aware of this possibility but it did not consider this curtailed the Member States' freedom in this field.

Whereas the ECJ refuses to forbid Member States from developing the political status of third-country nationals, it emphasises that this freedom is not absolute. The ECJ considers that the people who are granted such electoral rights must have a close link with the Member State in question ${ }^{67}$ and that in any case the Member States must observe Community law and the classical principles of equality and proportionality. Furthermore, the ECJ seems to have been influenced by the constitutional tradition of the United Kingdom. ${ }^{68}$ All this shows that the Court is certainly conscious that granting non-EU citizens electoral rights is a particularly sensitive question and that it therefore cannot be too liberal in this respect. The Advocate General went a step further. He asserted that third-country nationals could only be granted voting rights at European elections in 'exceptional circumstances'. ${ }^{69}$ Although the Advocate General did not explain exactly what those circumstances are, this is going too far in my opinion. This could mean that a Member State is not free to grant immigrants who have been legally resident in its territory for a long period the right to vote and to stand as a candidate in European elections. Such a restrictive solution runs counter to the subsidiary character of the main part of the European Parliament election's procedure,

\footnotetext{
66 Ibid para 77.

67 Ibid para 76.

68 Ibid paras 63 and 79. The emphasis of the Court on this element means in particular that there exists no common point of view between the EU Member States to grant thirdcountry nationals a harmonised political status. As a consequence, no redefinition of fundamental rights is possible through Art 6(2) EU. This constitutional tradition had already been noticed by the ECJ in the Kaur judgment. See above n 62 para 20.

69 Para 103 of the conclusions.
} 
but also the increasing tendency to grant third-country nationals possibilities to have their views taken into account at the political level.

The second ground invoked by Spain raises more difficult questions. Annex I of the 1976 Act limits the European Parliament elections in the United Kingdom to the sole territory of this Member State. Its overseas zones of influence were therefore excluded. As mentioned above, the ECtHR declared that this limitation breached the right to free elections in Gibraltar, an area where Community law is applicable. Consequently, European Parliament elections had to be organised by the United Kingdom on this territory. Spain claimed, however, that this judgment did not imply an extension of the European Parliament election to QCCs, who are not British citizens. The United Kingdom could only breach primary law (the Annex) when this is necessary for the protection of a fundamental right, according to Article 6(2) EU. Current interpretation of the ECHR and its Protocols, in particular Article 3 of the First Protocol, still allows States to apply nationality conditions in electoral matters. This also holds true for legislative polls. Since QCCs are not citizens of the United Kingdom for the purposes of the elections, the United Kingdom could not proceed with the extension.

Contrary to the first ground of action, the Advocate General and the ECJ defend opposite views here. Whereas the first almost totally agrees with Spain's reasoning, ${ }^{70}$ the ECJ argues that if the United Kingdom extended the right to vote and to stand as a candidate in European elections to $\mathrm{BCCs}$, this was in order 'to enable the Gibraltar electorate to vote in elections to the European Parliament as part of and on the same terms as the electorate of an existing United Kingdom constituency'. The United Kingdom therefore modified its legislation 'to comply with the requirements resulting from those "same terms". ${ }^{71}$ In rather terse terms, the Court then concludes that the United Kingdom's extension does not breach Community law. Why did the ECJ reject Spain's argument? In my opinion, this solution cannot be the direct result of the Matthews judgment of the ECtHR: ${ }^{72}$ indeed, and as already mentioned, this case only concerned British nationals who reside in Gibraltar. Therefore, it did not impose as such that the United Kingdom grant the QCCs residing in Gibraltar voting rights in the European elections. Although it is not obvious in the terms of the judgment itself, the Court seems aware nevertheless that $\mathrm{QCCs}$ are granted voting rights in European elections when they reside in the United Kingdom itself. If the United Kingdom had not allowed the $\mathrm{QCCs}$ to take part in elections to the EP in Gibraltar, this would have

\footnotetext{
70 Ibid para 128.

71 Case C-145/04 paras 91 and 93.

72 Compare L Burgogue-Larsen (n 2) 41-43.
} 
meant that the $\mathrm{BCCs}$ could in the future have lost those voting rights when residing in the United Kingdom. In other words, any solution other than extending EU voting rights to the QCCs in Gibraltar could have been discriminatory among the QCCs themselves. ${ }^{73}$ Contrary to the argumentation of Advocate General Tizzano, a departure from the requirements of the Annex could be therefore indispensable to the protection of a fundamental right, i.e. the non-discrimination principle. ${ }^{74}$

This explains why several British members of the EP, including Glyn Ford, Neil Parish, Graham Watson and Roger Knapman, applauded the judgment of the ECJ not only because it allows the United Kingdom to grant $\mathrm{QCC}$ s residing in Gibraltar voting rights in European elections, but first of all because it protects those electoral rights for QCCs residing in the United Kingdom. ${ }^{75}$ In other words, QCCs are not British citizens and thus cannot demand the automatic right to vote and to stand as a candidate in European elections on the basis of Article 3 of the First Protocol. Nevertheless, whenever they are under the 'jurisdiction' of a Member State of the Council of Europe they enjoy the guaranteed right of equal treatment under Article 14 ECHR.

One objection could be that Article 16 ECHR provides that '[n]othing in Articles 10, 11 and 14 shall be regarded as preventing the High Contracting Parties from imposing restrictions on the political activity of aliens'. This article confirms that limitations to the political rights of nonnationals are in principle admissible. This provision must be nevertheless correctly understood. As is widely confirmed by the case law of the ECtHR, it means that the nationality criterion is not discriminatory regarding electoral matters. Yet to my mind, Article 16 could not be used to justify discriminatory rules within a category of third-country nationals. In such a case, the question is no longer about restrictions to their political rights, but about a coherent policy in political matters. It would hardly be acceptable to grant some third-country nationals political rights while at the same time refusing those rights to other third-country nationals who are objectively in the same situation, for example because of their common historical link with the State of residence. Anyway, and more fundamentally, the ECJ was free and was even encouraged to provide a higher protection of fundamental rights than that required by the ECHR and its protocols. In its Bosphorus judgment, the ECtHR went so far as

\footnotetext{
73 Ibid para 79. For a summary of the argument of the United Kingdom in this respect, see also para 47. For another explanation of the Court's solution, mainly based on the 2002 Declaration, see M Claes (n 2) 217.

74 See contra A Dawes (n 2) 712.

75 V Miller, Gibraltar: diplomatic and constitutional developments (House of Commons Library, International Affairs and Defence Section, Research Paper 06/48, London 2006) 41 and 42.
} 
not to control the activity of EU institutions, provided EU law guarantees an 'equivalent protection' of fundamental rights. ${ }^{76}$ This last element has also certainly been a contributory factor in the thinking of the ECJ when it avoids being too explicit in its final ratio decidendi. Faced with such a delicate question of discrimination in the field of political rights, the ECJ has protected the Community legal order by giving precedence to the solution which most protects fundamental rights without going to any great lengths to explain why.

\section{Can EU citizens residing outside the Union be excluded from the right to vote and to stand as a candidate in elections to the European Parliament?}

This second question is related to the Eman \& Sevinger case (Case C-300/04). In its judgment, the ECJ entirely followed the Advocate General. ${ }^{77}$ Here, the legal exclusion of certain Dutch State citizens residing in Aruba, an island belonging to the Kingdom of the Netherlands, from the right to vote and stand as a candidate in European elections was at stake. An important feature of the case is that those rights were recognised for Dutch nationals residing abroad but other than in Aruba or the Dutch Antilles.

The ECJ decided in Eman \& Sevinger that citizenship rights are available in principle to all Member States' nationals, even when they reside outside the Community. ${ }^{78}$ This was a reply to the Dutch government's argument that EU citizenship rights should only be available on the territory of the Community. ${ }^{79}$ Beyond this general contention, the ECJ again considers that the identification of the holders of the right to vote and to stand as a candidate in European elections currently belongs to each Member State in compliance with Community law. ${ }^{80}$ In the absence of common rules, it is for the Member States to adopt the rules

76 ECtHR Case Bosphorus Hava Yollari Turzim ve Ticaret Anonim Sirketi v Ireland (2005) App $\mathrm{n}^{\circ}$ 45036/98. See S Adam and F Krenc, 'La responsabilité des Etats membres de l'Union européenne devant la Cour européenne des droits de l'homme' (2006) 6 JT 85-87 and A Hinerajos Parga, 'Bosphorus v. Ireland and the protection of fundamental rights in Europe' (2006) $31 \mathrm{EL}$ Rev 259. See also, for a good example of the self-restraint of the ECJ, Case C-36/02 Omega Spielhallen [2004] ECR I-9609 and the comments of T Ackermann (2005) 42 CML Rev. 1107 to 1120 and A Alemanno, 'A la recherche d'un équilibre entre libertés fondamentales et droits fondamentaux dans le cadre du marché intérieur' (2004) 4 Revue du droit de l'Union européenne 709 to 751. Compare with ECJ Case C-60/00 Carpenter [2002] ECR I-6279.

77 See para 168 of the conclusions of AG Tizzano.

78 According to the ECJ, answering the first question asked by the Raad van State, Dutch citizens residing in Aruba 'may rely on the rights conferred on citizens of the Union in Part Two of the Treaty'. See ECJ Case C-300/04 para 29.

79 Ibid para 25.

80 Ibid para 45. See also Case C-145/04 para 78. 
which are best adapted to their constitutional structure. ${ }^{81}$ The circumstance that some States - like France - organise European elections in overseas countries where Community law does not apply entirely is not a reason to make this practice compulsory for the other Member States. Furthermore, such rights can be subject to conditions. ${ }^{82}$ Whereas EC law does not apply in Aruba - the territory where Eman and Sevinger reside Article 3 of the First Protocol to the ECHR does not apply in this case. ${ }^{83}$ As a consequence, the applicants cannot require the Netherlands to provide them with active and passive voting rights in European elections. The ECJ recalls here the case law of the ECtHR according to which limitations to political rights through residence criteria are not contrary to the ECHR and its protocols as such. ${ }^{84}$

Notwithstanding this conclusion, the ECJ observes that 'the principle of equal treatment prevents [...] the criteria chosen from resulting in different treatment of nationals who are in comparable situations, unless that difference in treatment is objectively justified'. According to the Court, the Netherlands did not sufficiently justify why they allow all their citizens residing abroad to take part in the European elections, except those residing in the Dutch Antilles or in Aruba ${ }^{85}$ In comparison with the judgment in Case C-145/04, the ECJ analysed more explicitly the conformity of national legislation with the non-discrimination principle. Admittedly, the fundamental rights question here was easier to solve than in the Gibraltar case. Anyway, both judgments provide a high level of protection of fundamental rights, especially regarding the non-discrimination principle.

In its judgment following the preliminary ruling of the ECJ, the Dutch supreme administrative court confirmed the illegality of this exclusion. The Dutch authorities failed again to provide any objective justification for the difference in treatment. ${ }^{86}$ However, according to this judgment, it is for the Dutch political authorities to decide on a solution in the future, and anyway before the next elections to the EP in 2009. This solution might not necessarily imply that Dutch citizens residing in Aruba would be granted the right to vote and stand as a candidate in European elections, provided that the discrimination issue is solved. Moreover, the judgment made it clear that the illegality was limited to the sole provisions of Dutch law related to elections to the EP and did not extend to national elections.

\footnotetext{
81 Ibid para 50.

82 Ibid paras 52 and 53.

83 Ibid paras 48 to 50 .

84 See ECtHR Case Melnitchenko $v$ Ukraine (2005) App $\mathrm{n}^{\circ} 17707 / 02$. See also ECtHR case Hilbe $v$ Liechtenstein (1999) App n ${ }^{\circ} 31981 / 96$.

85 Case C-300/04 paras 60 and 61.

86 Raad v. State 21 Nov 2006, 200404446/1 \& 200404450/1 para 2.3.1.
} 
It is important here to mention that Eman and Sevinger had brought a parallel case before the Dutch supreme administrative court, complaining against their exclusion from voting rights in the election of the Tweede Kamer der Staten-Generaal (Second National Chamber of the Netherlands). ${ }^{87}$ The reason for the refusal was that they had not been residing in the Netherlands for a minimum period of ten years. The link with the Netherlands would be therefore too weak to grant Eman and Sevinger active and passive voting rights for the appointment of the Second National Chamber. Again, Dutch citizens not residing in Aruba or in the Dutch Antilles were granted those rights, even if they had never resided in the Netherlands. The Dutch supreme administrative court rejected the claims. According to its judgment, Eman and Sevinger could participate in the election of the parliamentary organ of Aruba, which is widely involved in the legislative process of the Kingdom of the Netherlands. ${ }^{88}$ The situation of Dutch citizens residing in the Netherlands and in Aruba is therefore different regarding 'national' elections, so that no discrimination can be identified. ${ }^{89}$

This result was opposite to what the Raad van State had decided in the case concerning European elections. The reason for this discrepancy lies precisely in the difference between the two situations that must be compared in both cases. ${ }^{90}$ In the case concerning national elections, both categories of Dutch citizens did not elect the same legislative organ: the representative organs of Aruba or the Dutch Antilles when the voters resided in those territories, ${ }^{91}$ and the Second National Chamber of the Netherlands in other cases. On the contrary, in the case concerning European elections, the sole election at stake was that to the EP. Even if Community law did not apply outside the Netherlands, the difference introduced by Dutch law regarding European elections between Dutch citizens living in Aruba and the Dutch Antilles on one hand and those living abroad but not in those territories on the other hand ${ }^{92}$ was therefore discriminatory because it concerned the same legislative organ and was not justified on sufficient objective grounds.

\footnotetext{
87 Raad v. State 21 Nov 2006, 200607567/1 \& 200607800/1. See also M Claes (n 2) 218.

88 Ibid para 2.3.2.

89 Ibid paras 2.3.3. and 2.4.1.

90 Between Dutch citizens residing in Aruba or the Dutch Antilles on the one hand and those who do not live in the Netherlands but live elsewhere, other than in Aruba or the Dutch Antilles on the other hand.

91 These people could also participate in the election of the Second National Chamber of the Netherlands if they had resided for at least ten years in the Netherlands.

92 See Case 300/04 para 58.
} 


\section{A comparison between 'economic-oriented' and 'political-oriented' rights linked to EU citizenship: a several-speed Europe of citizens?}

The recent case law of the ECJ regarding elections to the EP raises once again questions as to the coherence of European citizenship as a whole. ${ }^{93}$ A comparison between those judgments and the case law of the ECJ revolving around 'economic-oriented' freedoms results in quite a paradoxical picture: on the one hand the Court underlines the existence of a specific European citizenship, which undoubtedly is significant in the sphere of political rights such as the right to petition, the passive and active right to take part in elections to the EP, etc.; on the other hand, the Court shows restraint when defining the scope of those EU citizenship 'political' rights.

Before entering into this discussion, let us make an observation as to the principle itself of the intervention of the ECJ in cases like Spain $v$. United Kingdom and Eman \& Sevinger. Certainly, these judgments concerned purely internal situations, even though they related to the conditions of enjoyment of Community voting rights. Contrary to most of the following judgments linked to the four Community freedoms, there was no cross-border element here that 'naturally' justified the intervention of the Court of Justice. After all, Art 19(2) EC only provides that 'every citizen of the Union residing in a Member State of which he is not a national shall have the right to vote and stand as a candidate in elections to the European Parliament in the Member State in which he resides, under the same conditions as nationals of that State'. ${ }^{94}$ The ECJ therefore had maybe less room for manoeuvre when faced with situations where, as was the case in both of the commented judgments, no EU citizen was deprived of a Community right when travelling within the Union.

Admittedly, however, the right to vote and stand as a candidate in European elections is independent of any movement within the Union. As mentioned, voting rights in European elections are a result not of the EC Treaty itself but of the 1976 Act on the Election of the Representatives of the European Parliament by Direct Universal Suffrage, which completed the founding treaties. ${ }^{95}$ According to this Act, each EU citizen enjoys the right to vote and stand as a candidate in European elections when residing in a territory where the EP is a legislative organ, under the conditions established by the European Council and the Member States themselves. No condition other than possessing the nationality of a Member State is

\footnotetext{
93 See also S Wernicke, 'Au nom de qui? The European Court of Justice Between Member States, Civil Society and Union Citizens' (2007) 3 ELJ. 384-386.

94 Emphasis added. The ECJ insisted on the limited scope of this provision in the Gibraltar Case. See Case C-145/04 para 66.

95 See $\mathrm{n} 10$.
} 
required to enjoy these EU citizenship rights, especially not a cross-border element. Thus, in my opinion, the competence of the ECJ to give a preliminary ruling in the Dutch case and to assess the compliance of the United Kingdom's EPRA with Community law could not be questioned. ${ }^{96}$ This is all the more true since Art $220 \mathrm{EC}$ as such does not subordinate the competence of the ECJ to any cross-border requirement.

\section{EU Citizenship rights before the ECJ: discrepancies between the freedoms of movement and of residence and EU electoral rights?}

The freedoms of movement and of residence are essential Community rights. They are not only qualified as citizenship rights set out in part two of the EC Treaty, but occupy an essential position within the Treaty chapters devoted to Community policies. The role played by the ECJ in establishing the Union's constitutional foundations has been significant in interpreting these rights. Several cases illustrate this observation.

The freedoms of movement and of residence were basically only applicable to persons exercising an economic activity. The ECJ has nevertheless construed this condition broadly. In its Franca Ninni-Orasche judgment, for example, the ECJ considered that employment of two and a half months could be classed as an economic activity "provided that the activity performed as an employed person is not purely marginal and ancillary'. ${ }^{97}$

But even in those cases where a person does not exercise an economic activity, the ECJ has given a wide interpretation to Articles 12, 17 and 18 EC. ${ }^{98}$ The ECJ only makes use of these provisions when other Treaty bases - such as Articles 39 or 43 EC - are not applicable. ${ }^{99}$ In D'Hoop, a case about students, the ECJ decided that EU citizenship 'precludes a Member State from refusing to grant the tideover allowance to one of its nationals, a student seeking her first employment, on the sole ground that that student completed her secondary education in another Member State'. ${ }^{100}$ In the Baumbast judgment, the Court added that the freedoms of movement and of residence are only admissible when the citizens in question do not represent an 'unreasonable burden on the

\footnotetext{
96 An author criticised the ECJ for not having explained the grounds of its competence in these cases. See M Claes (n 2) 216.

97 See ECJ Case C-413/01 Franca Ninni-Orasche [2003] ECR I-13187 para 32.

98 See M Dougan, 'The Constitutional Dimension to the Case Law on Union Citizenship' (2006) 5 EL Rev 613-641.

99 See for example ECJ Case C-258/04 Ioannidis [2005] ECR I-8275 paras 20 and following.

100 See ECJ Case C-224/98 D’Hoop [2002] ECR I-6191 para 40.
} 
public finances of the host State'. ${ }^{101}$ The Trojani case concerned persons who were not studying or exercising an economic activity but who had worked in their country of residence in the past. ${ }^{102}$ The Court introduced a distinction here between the residence of EU citizens and the granting of social rights to persons whose right to live in their Member State of residence is not contested. Whereas in the first case the criterion of economic dependence can validate limitations of the right to freely reside in another Member State, in the second case such a limitation must be considered as discrimination on the grounds of nationality, which is forbidden by Article $12 \mathrm{EC}$. This case law has been confirmed in the Bidar case concerning a French student who was legally resident in the United Kingdom. As a result of his French nationality, the United Kingdom refused to grant him financial assistance to cover his maintenance costs during his university studies. The ECJ decided that the English system breached the non-discrimination principle contained in Article 12 EC. ${ }^{103}$

More generally, the ECJ sanctions Member States when they discourage their own non-economically active citizens to be a resident of another Member State by subordinating the granting of an advantage to the condition that they reside on the national territory. Apart from the D'Hoop case above, the Pusa case also illustrates this ban. In this case, a disadvantageous fiscal regime applied to nationals residing abroad was the subject of contention. ${ }^{104}$ Another good example is the Tas-Hagen case concerning the refusal to grant an allowance to civilians who are victims of war but who reside outside their national territory. ${ }^{105}$ The Morgan and Bucher cases, still pending, raise identical problems concerning students who wish to receive financial aid from their Member State but who study abroad. ${ }^{106}$

\footnotetext{
101 See ECJ Case C-413/99 Baumbast [2002] ECR I-7091 paras 90 and 94.

102 See ECJ Case C-456/02 Trojani [2004] ECR I-7573 para 33.

103 See ECJ Case C-209/03 Bidar [2005] ECR I-3119 paras 42 to 44.

104 See ECJ Case C-224/02 Pusa [2004] ECR I-4763 para 19.

105 See ECJ Case C-192/05 Tas-Hagen [2006] ECR I-10451 para 40. An almost similar question is currently pending before the ECJ concerning the granting by Poland of an allowance to victims of concentration camps. This country excludes from this advantage people residing in another State, be it an EU Member State or not (ECJ Case C-499/06 Nerkowska still pending). In its Baldinger judgment, which concerned a limitation of war allowances to nationals, the Court interpreted the question asked by the national judge in a quite surprisingly restrictive way. The Court answered that such a national limitation was not contrary to the freedom of movement of migrant workers. It is true that the question concerned only the applicability of article 39(2) EC to Mr Baldinger and a direct discrimination. However, the ECJ did not assess whether Mr Baldinger could win his proceedings by invoking citizenship rights, amongst which the non-discrimination principle of article 12 EC (ECJ Case C-386/02 Baldinger [2004] ECR I-8411). AG Dámaso Ruiz-Jarabo Colomer concluded on the contrary that Art 12 EC forbade that a Member State applies the nationality criterion in granting war allowances.

106 See ECJ Case C-11/06 Morgan, still pending and ECJ Case C-12/06 Bucher, pending. See the conclusions of AG Dámaso Ruiz-Jarabo Colomer issued on 20 March 2007.
} 
Furthermore, the ECJ judged in the above-mentioned Micheletti case that the sole fact that a national of a Member State holds the nationality of a third-country is no reason to refuse him/her the benefit of Community law, especially the right to freely move within the Union. ${ }^{107}$ According to the ECJ, 'the provisions of Community law on freedom of establishment preclude a Member State from denying a national of another Member State who possesses at the same time the nationality of a non-member country entitlement to that freedom on the ground that the law of the host State deems him to be a national of the non-member country'. This conclusion is not affected by the circumstance that nationality policies are part of Member States' competences. ${ }^{108}$ In other terms, a Member State cannot invoke its own rules of private international law to exclude the application of the Community freedoms of movement to bi-nationals who have the nationality of a Member State. The same conclusion applies a fortiori to EU citizens who are simultaneously nationals of several Member States. ${ }^{109}$ A similar reasoning can be found in the Saldanha case, which concerned the requirement by Austria of a guarantee of coverage of procedural costs from foreigners who are plaintiffs in proceedings before Austrian courts, ${ }^{110}$ and in the Zhu \& Chen case, where the freedom of residence of a Community national was at stake. ${ }^{111}$ As well summarised in the famous Grzelczyk judgment,

'Union citizenship is [therefore] destined to be the fundamental status of nationals of the Member States, enabling those who find themselves in the same situation to enjoy the same treatment in law irrespective of their nationality, subject to such exceptions as are expressly provided for'. ${ }^{112}$

In the field of electoral rights, the ECJ rather observes that nationality questions are still a matter for national competence. It is therefore currently for the Member States to determine who enjoys active and passive voting rights in European elections, and this in compliance with Community law. This implies that in principle the Member States may grant citizens of third-countries such rights or exclude their own citizens residing outside Europe from benefiting from them. However, and as already mentioned, the recent judgments of the ECJ do not grant the

\footnotetext{
107 See n 22 para 15.

108 Ibid para 10.

109 See ECJ Case C-148/02 Garcia Avello [2003] ECR I-11613 paras 22 to 29. See T Ackermann (2007) 1 CML Rev 141-154.

110 See ECJ Case C-122/96 Saldanha [1997] ECR I-5325 para 30.

111 See ECJ Case C-200/02 Zhu \& Chen [2004] ECR I-9925.

112 ECJ Case C-184/99 Grzelczyk [2001] ECR I-6193 para 31.
} 
Member States total freedom in this respect. ${ }^{113}$ The extension of voting rights to non-EU citizens seems to be possible only when a close link can be identified with the Member State in question. Furthermore, the ECJ in its recent judgments apparently took into account the constitutional tradition of the United Kingdom and the specific state structure of the Netherlands, although it is not clear whether and to what extent the ECJ considers such peculiarities to be a real condition for any differentiation in European voting rights. ${ }^{114}$ Anyway, a limitation of these rights on grounds of residence criteria is only acceptable in accordance with the general principles of Community law, especially the non-discrimination principle.

Nevertheless, this relative prudence on the part of the ECJ is not the result of any shyness. This is rather the consequence of the lack of consensus among Member States to determine precisely who benefits from the voting rights in European elections. This lack of consensus about the political aspects of EU citizenship is well illustrated by the Charter of Fundamental Rights, intended as the first autonomous corpus of human rights of the EC/EU. Contrary to electoral rights, this Charter expressly provides that 'freedom of movement and residence may be granted, in accordance with the Treaty establishing the European Community, to nationals of third countries legally resident in the territory of a Member State'. ${ }^{115}$ A comparable provision concerning electoral rights has neither been inserted in the Charter nor in the Constitutional Treaty. This could mean that whereas the freedoms to move and to reside within the Union are natural Community rights and could even be extended to third-country nationals, voting rights, because of their political sensitivity, remain essentially a matter of national competence.

\section{An 'à la carte' EU citizenship? Realism in the analysis of the consequences of Spain $v$ United Kingdom and Eman \& Sevinger}

The foregoing developments might give the impression of an $\grave{a}$ la carte EU citizenship, determined according to the type of right and the place where it is invoked. ${ }^{116}$ Singularly, the case law of the ECJ seems to

\footnotetext{
113 See also the conclusions of the AG Tizzano para 64.

114 In the Gibraltar case, the ECJ seems to have been sensitive to the fact that the extension of voting rights to $\mathrm{QCC}$ was also foreseen for national elections. See Case 145/04 para 79.

115 Art 45(2). See for an application Directive (EC) 2004/38 of 29 April 2004 on the right of citizens of the Union and their family members to move and reside freely within the territory of the Member States amending Regulation (EEC) No 1612/68 and repealing Directives 64/221/EEC, 68/360/EEC, 72/194/EEC, 73/148/EEC, 75/34/EEC, 75/35/EEC, 90/364/EEC, 90/365/EEC and 93/96/EEC [1993] OJ L229/35.

116 F Kauff-Gazin (n 2) 9.
} 
be more far-reaching when dealing with the freedoms of movement than when fixing some boundaries of the Member States' freedom regarding EU electoral rights. But the consequences of the judgments of the ECJ dated 12 September 2006 should not be exaggerated.

Firstly, as already noted, the ECJ does not give the Member States complete freedom when defining the groups of persons enjoying voting rights in European elections. The core groups of beneficiaries are no doubt Member States' nationals, and any exception to this principle seems to be subordinated to some specific explanation. It is not relevant to repeat here the reasoning of the ECJ.

A second reason is that, contrary to Kauff-Gazin's assertion, in my opinion those judgments do not change anything in the Micheletti case law. ${ }^{117}$ The ECJ has indeed sufficiently emphasised the scope of the recent judgments: they concern only purely political rights, such as the right to vote or to stand as a candidate in European elections. When economic or social rights are at stake, it remains the case that Community law exercises a considerable influence on the Member States, even with regard to nationality questions. The Member States have definitely lost a part of their sovereignty in these fields.

The third reason is a direct consequence of the case law of the ECtHR. If the ECJ allows a Member State to exclude nationals from European elections when they reside outside the national territory, this conclusion, as a result of Matthews, is limited to territories where the EP plays no part as a legislative organ. In other cases, EU nationals must have the right to choose their deputies to the EP and stand as a candidate therefor.

Last, and as already mentioned, the ECJ point of view is perfectly respectful of the constitutional reality framed by primary law. Rights to political participation are indeed very poorly defined in the EC Treaty and the 1976 Act, while economic freedoms are an essential part of the Community policy. As for the reference in Articles 189 and 190 EC to the 'peoples' of Europe when they describe the Members of the EP, such a concept is quite theoretical and vague. Moreover, it is capable of different meanings in the Member States. Consequently, in the commented judgments, the Court was not privileging one solution over another on grounds of the potential scope of the 'European peoples'. For all these reasons, nothing could justify, in my opinion, the ECJ going further in harmonising the scope ratione personae of elections to the EP.

117 Ibidem. 


\section{v. Conclusion}

This leads us to some conclusive remarks. The current fundaments of EU citizenship are weak, especially in the field of political rights. This is in particular the result of the lack of sufficiently harmonised procedural rules for elections to the European Parliament. The sheer number of members of the EP, the existence of national constituencies and, last but not least, the fact that European voters do not exercise a direct choice of members of the future European Commission prevent European Parliament elections from being any true citizens' forum for EU politics. ${ }^{118}$ As clearly illustrated by the continuously low voter turnout in European elections - even in $2004^{119}$ - the differences highlighted in this article between the various EU citizenship rights certainly do not improve the Union's general public image. ${ }^{120}$ However, as evidenced by the judgments Spain v. United Kingdom and Eman \& Sevinger, the ECJ certainly could not be held responsible for this situation. The problem is of a constitutional nature. For this reason, the significance of European elections in the European democratic process should be discussed globally once again at the political level.

\footnotetext{
118 See S Strudel, 'La mise en oeuvre de la citoyenneté européenne dans les Etats membres. La citoyenneté européenne: "une réalité embarrassante"?' in S Leclerc and J-F AkandjiKombé (eds), La citoyenneté européenne (Bruylant, Brussels 2007) 99. See also the intervention of Prof. K Lenaerts at the Belgian Parliament on 17 March 2007 (Belgian Parliament, Compte-rendu intégral, Doc. Ch., sess. 2006-2007, 9 March 2007, COL 029, 58 <www. lachambre.be/kvvcr/pdf_sections/pri/europe/COL029_PR.pdf> accessed 15 May 2007).

119 Communication from the European Commission of 12 December 2006, Commission report on the participation of European Union citizens in the Member State of residence (Directive (EC) 93/109) and on the electoral arrangements (Decision 76/787/EC as amended by Decision 2002/772/EC, Euratom), COM(2006) 790 final 5-8. See also M Franklin, 'European elections and the European voter' in J Richardson (ed), European Union. Power and Policy Making ( $3^{\text {rd }}$ edn Routeledge, Oxon 2006) 233-237.

120 They also demonstrate that the Union is no federal State since nationality remains the competence of the Member States. See R Kovar and D Simon (n 5) 294. See also A Von Bogdandy, 'The Prospect of a European Republic: What European Citizens are Voting On' (2005) 42 CML Rev 913-941.
} 